\title{
Complex associations between periodontitis and cerebrovascular disease
}

\author{
Asocieri complexe ale parodontitei cu boala cerebrovasculară
}

\author{
Cristina Andrada Costea ${ }^{1}$, Iulia Cristina Micu', Andrada Șoancă ${ }^{1}$, Ștefan Ioan Stratul', \\ Andreea Ciurea ${ }^{1}$, Alexandra Roman ${ }^{1}$ \\ ${ }^{1}$ Disciplina de Parodontologie, Universitatea de Medicină și Farmacie „Iuliu Hațieganu“, \\ Cluj Napoca, România \\ 2Disciplina de Parodontologie, Universitatea de Medicină și Farmacie „Victor Babeș", \\ Timișoara, România
}

\begin{abstract}
Aim. All the data from the literature suggests a strong association between periodontitis and stroke, but the conclusions were heterogeneous. Also, longitudinal studies report an increased risk for stroke in patients with periodontitis. This article aimed to investigate through the most recent evidence, the relation of association between periodontitis and stroke and its clinical significance.

Methods. A well structured strategy was applied to Pubmed database. The last research was performed in 1st of July 2020.

Results. From all 490 articles initially selected only 18 corresponded with the inclusion criteria from this review. Periodontitis was associated with stroke and it also represented an independent risk factor for ischemic stroke. The periodontal treatment may reduce the risk for primary stroke or recurrent stroke.

Conclusions. The data presented in this article support the relation of association between periodontitis and stroke. Oral health and the treatment of infectious and inflammatory oral conditions are very important not only for maintaining oral health but also for maintaining systemic health.
\end{abstract}

Keywords: systemic inflammation, periodontitis, ischemic stroke

\begin{abstract}
Scop. Datele din literatură sugerează existența unei asocieri între parodontită și accidentul vascular cerebral (AVC), dar concluziile sunt heterogene. De asemenea, studiile longitudinale raportează o creștere a riscului de accident vascular la pacienții cu parodontită. Scopul studiului a fost de a investiga, pe baza celor mai recente informații, relația de asociere dintre parodontită și AVC și semnificația clinică a eventualei asocieri.

Metodă. O strategie de căutare structurată a fost aplicată bazei de date electronice Pubmed. Ultima căutare a fost realizată în 1 iulie 2020 .

Rezultate. Dintre cele 490 de articole selectate inițal, doar 18 au corespuns criteriilor de includere în review. Parodontita a fost asociată cu AVC și a reprezentat un factor de risc independent pentru AVC ischemic. Tratamentul parodontitei poate reduce riscul pentru AVC primar sau AVC recurent.

Concluzii. Datele prezentate în acest articol susțin relația de asociere între parodontită și AVC. Sănătatea orală și tratamentul afecțiunilor inflamatorii și infecțioase orale sunt foarte importante, nu doar pentru menținerea sănătății orale, dar și pentru menținerea unui status de sănătate sistemică.
\end{abstract}

Cuvinte cheie: inflamație sistemică, parodontită, accident vascular cerebral ischemic

\section{INTRODUCERE}

Parodontita este o boală infecţioasă, de natură inflamatorie, cronică, care afectează şi distruge structurile de susţinere ale dintelui, mai precis osul alveolar, ligamentele parodontale, cementul şi ţesu- turile gingivale [1]. Parodontita este foarte frecventă în rândul populaţiei şi a fost asociată cu un risc crescut de producere a accidentului vascular cerebral prin mecanisme patologice încă insuficient elucidate [2]. Datele epidemiologice sugerează o 
legătură de asociere între accidentul vascular cerebral şi parodontită [3]. Această asociere a fost analizată în diferite tipuri de studii epidemiologice, cum sunt cele de tip cross-sectional, case-control sau studiile de cohortă.

Parodontita face parte din categoria celor mai frecvente boli inflamatorii cronice care aparţin speciei umane [4]. Parodontita are o prevalenţă estimată în rândul populaţiei între $20 \%$ şi $50 \%[5,6]$, iar aproximativ $10 \%$ dintre pacienţii bolnavi prezintă forme severe de parodontită, care pot avea un efect negativ asupra sănătăţii sistemice [6-8].

În studiul realizat asupra populaţiei din Statele Unite între anii 2009 şi 2012, autorii au estimat o prevalenţă a parodontitei de 45,9\% (reprezentând aproximativ 141 milioane de persoane) în rândul populaţiei adulte dentate, de peste 30 de ani, din Statele Unite. Dintre aceşti pacienţi, 8,9\% au suferit de forme severe de parodontită, iar $37,1 \%$ au avut forme mai puţin severe [5]. Datele epidemiologice din Germania arată o prevalenţă a parodontitei de 95\% în rândul adulţilor şi 99\% în rândul persoanelor peste 80 de ani [9].

Accidentul vascular cerebral reprezintă a doua cea mai comună cauză de mortalitate din lume $[10,11]$ şi este a treia cauză de dizabilitate în rândul adulţilor [12]. Aproximativ 80\% dintre accidentele vasculare cerebrale sunt cauzate de ischemia cerebrală focală datorată ocluziei cerebrale şi doar $20 \%$ sunt cauzate de hemoragie cerebrală $[13,14]$.

Parodontita şi accidentul vascular cerebral prezintă multipli factori de risc comuni, cum sunt vârsta, sexul, diabetul zaharat, hipertensiunea arterială sau hipercolesterolemia. Parodontita este asociată cu o creştere a markerilor inflamatori sistemici de tipul IL-6, proteinei C reactive şi TNF- $\alpha[15,16]$, printr-un mecanism cronic de expunere la bacterii Gram-negative [17,18], implicate în etiologia accidentului vascular cerebral şi a aterosclerozei [19].

$\mathrm{O}$ serie de review-uri sistematice au investigat relaţia dintre cele două afecţiuni [20,15], dar doar un review recent a evaluat interacţiunea cu diferitele tipuri de evenimente cerebrovasculare. Datele prezente în literatură sugerează existenţa unei asocieri complexe între parodontită şi boala cerebrovasculară, în special accidentul vascular cerebral, dar concluziile sunt heterogene. De asemenea, este raportată o creştere a riscului de accident vascular la pacienţii cu parodontită, în studii longitudinale.
Se consideră că aceste rezultate trebuie privite circumspect şi că, pentru obţinerea unor rezultate concludente, este nevoie de noi studii prospective, cu un design bine organizat, eventual care să investigheze şi relaţia parodontitei cu accidentul vascular cerebral la supravieţuitori [21]. În acest context, acest studiu şi-a propus să investigheze, pe baza celor mai recente informaţii, relaţia de asociere dintre parodontită şi accidentul vascular cerebral şi semnificaţia clinică a eventualei asocieri.

\section{MATERIAL ŞI METODĂ}

O strategie de căutare structurată a fost aplicată bazei de date electronice Pubmed. Ultima căutare a fost realizată în 1 iulie 2020. Au fost analizate articolele care investigau asocierea dintre boala parodontală şi accidentul vascular cerebral. Strategia de căutare a inclus doar publicaţiile în limba engleză, au fost folosiţi termeni combinaţi cum sunt: "stroke" OR "ischemic stroke" OR "hemoragic stroke" AND "periodontitis" OR "periodontal disease" . Selecţia articolelor a fost făcută pe baza unor criterii de includere şi excludere. Astfel, au fost excluse studiile care erau concentrate mai mult pe statusul de sănătate orală (pierderi dentare, status parodontal, leziuni carioase), fără a evalua asocierea cu patologie cerebrală. De asemenea, au fost excluse şi articolele care au avut titlul fără nicio conexiune cu asocierea studiată. Studiile cu un conţinut irelevant pentru asocierea studiată au fost excluse. Articolele rămase au fost sortate pe baza titlului şi a rezumatului.

\section{REZULTATE}

În urma aplicării strategiei de căutare, au fost găsite 490 de articole pentru a fi examinate. Au fost excluse 467 de articole pe baza titlului şi a rezumatului, din cauza lipsei conexiunii dintre acestea şi asocierea studiată. 23 de articole au rămas relevante pentru studiu. După examinarea conţinutului, au fost excluse încă 5 articole, din cauza conţinutului irelevant pentru asocierea studiată (Figura 1). Articolele incluse în acest studiu au fost desfăşurate în diferite părţi ale globului: Europa, Asia, America şi Africa. 


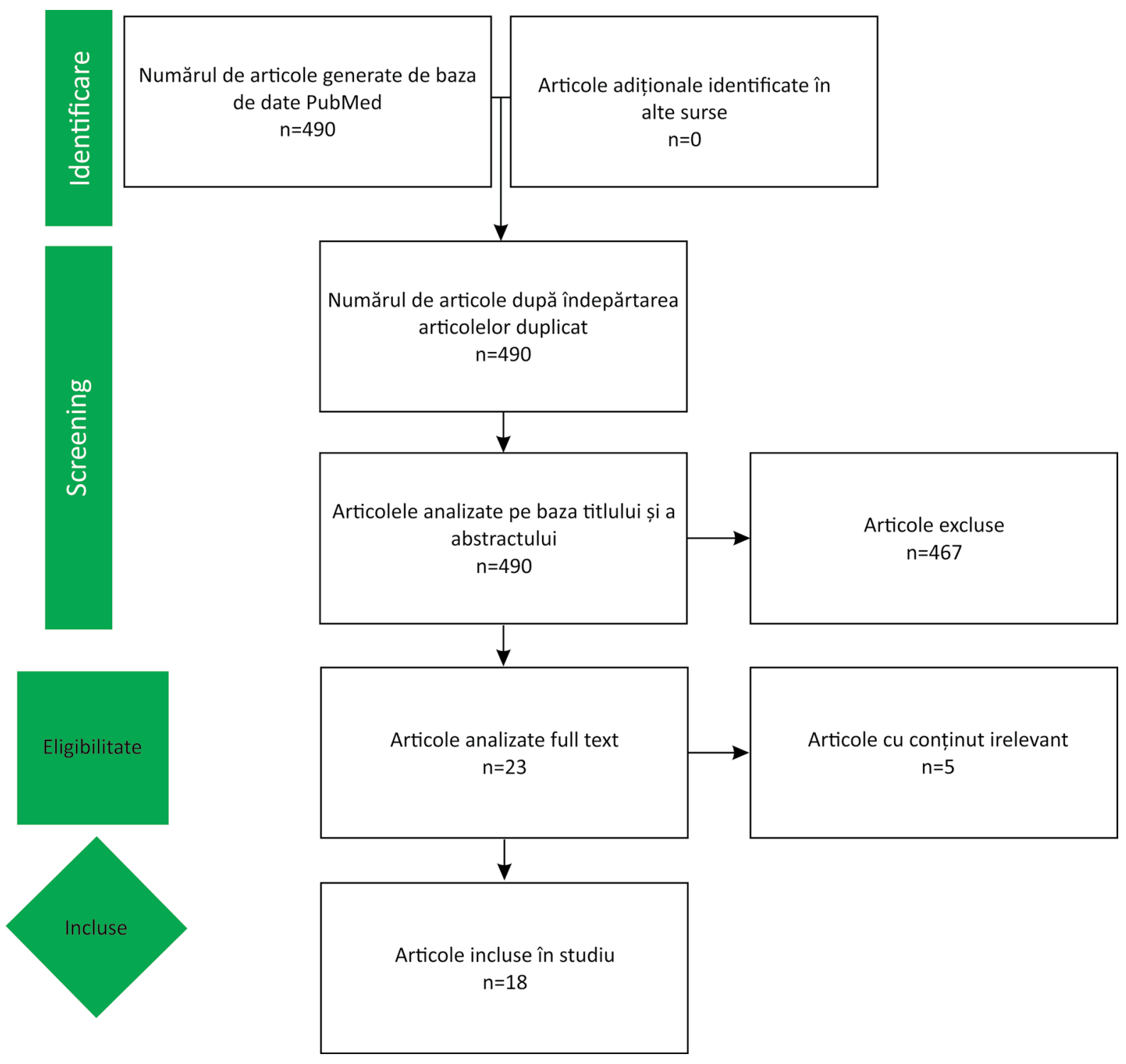

FIGURA 1. Diagrama flow a articolelor studiate

\section{Relaţia dintre parodontită şi accidentul vascular cerebral}

Toate cele 18 de articole analizate au raportat legătura asociativă dintre parodontită şi accidentul vascular cerebral. Două dintre cele 18 de articole studiate au analizat legătura dintre parodontită şi hemoragiile intracerebrale sau accidentul vascular cerebral hemoragic.

S-a raportat un număr mare de factori de risc comuni atât parodontitei, cât şi accidentului vascular. Multe dintre articolele analizate au inclus ca factori comuni vârsta, sexul, hipertensiunea arterială, fumatul, diabetul şi indicele de masă corporală pentru a identifica dacă parodontita reprezintă un factor de risc independent pentru accidentul vascular cerebral ischemic sau, mai degrabă, este un factor de risc asociat. Astfel, literatura arată că parodontita reprezintă un factor de risc independent pentru accidentul vascular cerebral ischemic.

\section{Markerii parodontali şi inflamaţia sistemică}

Majoritatea articolelor au raportat o conexiune puternică între markerii parodontali, cum sunt indicele de sângerare la sondare, pierderea de ataşament clinic, pungile parodontale profunde şi patologia cerebrovasculară, în particular accidentul vascular cerebral [22-26]. Inflamaţia sistemică a fost mecanismul patologic cel mai des folosit pentru a explica legătura dintre parodontită şi accidentul vascular cerebral ischemic $[15,16,20]$. Lafon şi colab. au arătat că markerii bolii parodontale - BoP, pierderea osoasă şi pungile parodontale profunde - 
TABEL 1. Principalele concluzii ale articolelor studiate

\begin{tabular}{|c|c|c|c|}
\hline $\begin{array}{l}\text { Primul } \\
\text { autor, } \\
\text { anul }\end{array}$ & Principala concluzie a studiului & Cele mai relevante rezultate & $\begin{array}{c}\text { Asocierea dintre } \\
\text { parodontită } \\
\text { şi AVC }\end{array}$ \\
\hline $\begin{array}{l}\text { Ghizoni, } \\
2012\end{array}$ & $\begin{array}{l}\text { Parodontita este un factor de risc pentru } \\
\text { dezvoltarea infarctelor cerebrale sau } \\
\text { hemoragice. }\end{array}$ & $\begin{array}{l}\text { Pacienţii cu AVC au avut: BoP crescut, niveluri } \\
\text { crescute de } P \text {. gingivalis în pungile profunde. } \\
\text { S-a găsit o corelaţie pozitivă între prevalenţa lui } P \text {. } \\
\text { gingivalis şi pierderile de ataşament la pacienţii cu } \\
\text { AVC ischemic. }\end{array}$ & DA \\
\hline Lee, 2013 & $\begin{array}{l}\text { Parodontita creşte incidenţa AVC, în special la } \\
\text { tineri. }\end{array}$ & Tratamentul bolii parodontale scade incidenţa AVC. & DA \\
\hline Soder, 2015 & $\begin{array}{l}\text { A fost sugerată o asociere între AVC şi } \\
\text { inflamaţia gingivală }\end{array}$ & $\begin{array}{l}\text { Inflamaţia gingivală a fost semnificativ crescută la } \\
\text { pacienţii cu AVC. }\end{array}$ & $\mathrm{DA}$ \\
\hline Sen, 2013 & $\begin{array}{l}\text { Există o legătură independentă între } \\
\text { evenimentele cerebrale vasculare recurente } \\
\text { (AVC recurent) şi pungile parodontale profunde. }\end{array}$ & $\begin{array}{l}38 \% \text { dintre pacienţii cu AVC au avut pungi } \\
\text { parodontale adânci şi } 26 \% \text { dintre ei au avut AVC } \\
\text { recurent. }\end{array}$ & $\mathrm{DA}$ \\
\hline $\begin{array}{l}\text { Hosomi, } \\
2012\end{array}$ & $\begin{array}{l}\text { Anticorpii anti } P \text {. gingivalis ar putea fi asociaţi } \\
\text { cu fibrilaţia atrială. }\end{array}$ & $\begin{array}{l}\text { Nivelurile de proteină C-reactivă din ser au fost } \\
\text { semnificativ asociate cu AVC ischemic. }\end{array}$ & DA \\
\hline Sim, 2008 & $\begin{array}{l}\text { Parodontita este un factor de risc independent } \\
\text { pentru AVC. } \\
\text { Legătura dintre AVC şi parodontită este foarte } \\
\text { puternică la adulţii tineri. }\end{array}$ & AVC a fost puternic asociat cu parodontita. & DA \\
\hline $\begin{array}{l}\text { Pradeep, } \\
2010\end{array}$ & $\begin{array}{l}\text { S-a sugerat o legătură între parodontită şi boala } \\
\text { cerebrovasculară. }\end{array}$ & Parodontita severă a fost puternic asociată cu AVC. & $\mathrm{DA}$ \\
\hline Diouf, 2015 & Boala parodontală este asociată cu AVC. & $\begin{array}{l}\text { Pungile parodontale profunde şi pierderile de } \\
\text { ataşament au fost asociate cu AVC. }\end{array}$ & $\mathrm{DA}$ \\
\hline Leira, 2015 & $\begin{array}{l}\text { Sănătatea orală a fost mai puţin satisfăcătoare } \\
\text { la pacienţii cu infarct lacunar. }\end{array}$ & $\begin{array}{l}\text { Parodontita cronică este asociată pozitiv cu } \\
\text { infarctul lacunar. }\end{array}$ & $\mathrm{DA}$ \\
\hline $\begin{array}{l}\text { Tonomura, } \\
2016\end{array}$ & $\begin{array}{l}\text { Proteinele lui Streptococus mutans ar putea fi } \\
\text { asociate cu hemoragiile intracerebrale. }\end{array}$ & $\begin{array}{l}\text { Proteina Cnm-pozitivă a lui Streptococcus mutans } \\
\text { a fost asociată cu hemoragia intracerebrală } \\
\text { hipertensivă. }\end{array}$ & DA \\
\hline $\begin{array}{l}\text { Del Brutto, } \\
2017\end{array}$ & $\begin{array}{l}\text { Edentaţia severă este un factor predispozant } \\
\text { major şi independent pentru AVC. }\end{array}$ & $\begin{array}{l}\text { Dintre } 22 \text { de cazuri cu AVC, } 14 \text { au avut edentaţie } \\
\text { severă. }\end{array}$ & $\mathrm{DA}$ \\
\hline $\begin{array}{l}\text { Pillai, } \\
2018\end{array}$ & $\begin{array}{l}\text { Parodontita şi pierderea dinţilor reprezintă } \\
\text { factori independent asociaţi cu AVC. }\end{array}$ & $\begin{array}{l}\text { Prevenţia, intervenţia timpurie şi tratamentul } \\
\text { parodontitei pot reduce incidenţa AVC. }\end{array}$ & $\mathrm{DA}$ \\
\hline Aarabi, 2017 & $\begin{array}{l}\text { Disfuncţia endotelială şi potenţiala implicare } \\
\text { a sistemului imunitar sunt presupusele } \\
\text { mecanisme de legătură între evenimentele } \\
\text { vasculare cerebrale şi parodontita. }\end{array}$ & $\begin{array}{l}\text { Parodontita agravează boala cerebrovasculară } \\
\text { şi demenţa şi creşte riscul pt AVC. Parodontita } \\
\text { interacţionează. }\end{array}$ & DA \\
\hline Huang, 2019 & $\begin{array}{l}\text { Tratamentul parodontal intensiv la pacienţii cu } \\
\text { parodontită poate reduce semnificativ riscul de } \\
\text { hemoragie intracerebrală. }\end{array}$ & $\begin{array}{l}\text { Hemoragiile intracerebrale au fost semnificativ } \\
\text { mai scăzute la grupul de pacienţi care a primit } \\
\text { tratament parodontal faţă de grupul control. }\end{array}$ & DA \\
\hline Sen, 2018 & $\begin{array}{l}\text { Parodontita reprezintă un factor de risc pentru } \\
\text { instalarea AVC ischemic. }\end{array}$ & $\begin{array}{l}\text { Inflamaţia gingivală crescută, parodontita } \\
\text { incipientă, ţesuturile cu inflamaţie severă cresc } \\
\text { riscul pentru AVC ischemic. }\end{array}$ & DA \\
\hline Palm, 2013 & $\begin{array}{l}\text { Inflamaţia sistemică crescută şi patogenii } \\
\text { parodontali prezenţi in salivă au fost asociaţi cu } \\
\text { AVC ischemic. }\end{array}$ & $\begin{array}{l}\text { Pacienţii cu AVC au avut frecvent semne de } \\
\text { parodontită în antecedente. }\end{array}$ & DA \\
\hline Leira, 2017 & $\begin{array}{l}\text { Parodontita în antecedente poate fi un factor } \\
\text { de risc moderat sau sever pentru AVC ischemic. }\end{array}$ & $\begin{array}{l}\text { Inflamaţia poate fi legătura dintre parodontită şi } \\
\text { AVC. } \\
\text { Riscul de AVC ischemic a fost crescut la pacienţii cu } \\
\text { parodontită. }\end{array}$ & DA \\
\hline $\begin{array}{l}\text { Lafon, } \\
2014\end{array}$ & $\begin{array}{l}\text { Principalii markeri ai bolii parodontale, indicele } \\
\text { de sângerare la sondare (BoP) şi pierderea } \\
\text { osoasă, au fost independent asociaţi cu AVC } \\
\text { ischemic. }\end{array}$ & $\begin{array}{l}\text { S-a raportat o puternică legătură între nivelurile } \\
\text { de proteină C reactivă pierderea osoasă, BoP, } \\
\text { hipertensiune şi AVC ischemic. }\end{array}$ & DA \\
\hline
\end{tabular}

BoP - Indicele de sângerare la sondare, AVC - accident vascular cerebral, P. gingivalis - Porphyromonas gingivalis

au fost independent asociaţi cu accidentul vascular cerebral ischemic. De asemenea, s-a relatat o asoci- ere între nivelurile proteinei $\mathrm{C}$ reactive, pierderea osoasă, BoP, hipertensiune şi AVC ischemic [27]. 
Del Brutto şi colab. sugerează că edentaţia severă este un factor independent major care precedă evenimentele vasculare cerebrale [28]. Chiar după controlul celorlalţi factori de risc, nivelurile de proteină C reactivă înalt sensibilă s-au asociat cu accidentul vascular cerebral ischemic [29].

Parodontita a fost independent asociată cu niveluri crescute de IL-6, ceea ce indică un puternic răspuns inflamator. Alte date din literatură sugerează o legătură între parodontită, răspuns inflamator sistemic şi disfuncţia endoteliului vascular, la pacienţii cu infarcte lacunare [30].

Huang şi colab. raportează că accidentele vasculare cerebrale hemoragice au fost semnificativ scăzute la pacienţii care au fost trataţi de parodontită faţă de pacienţii din grupul control, cu parodontită netratată [31].

\section{Patogenii parodontali şi accidentul vascular cerebral}

Soder şi colab. au arătat o corelaţie clară între inflamaţia gingivală şi accidentul vascular cerebral. Articolele au sugerat că parodontitele agresive, pozitive pentru Actinobacillus (Aggregatibacter) actinomycetemcomitans, care se dezvoltă de obicei la tineri, şi parodontita cronică a adultului s-au asociat cu un risc crescut de accident vascular cerebral [32]. S-a găsit o corelaţie pozitivă între prevalenţa lui Porphyromonas gingivalis şi pierderile de ataşament la pacienţii cu accident vascular cerebral ischemic [22].

\section{DISCUŢII}

Parodontita este o problemă importantă de sănătate publică din cauza prevalenţei crescute pe care o are în rândul populaţiei adulte din întreaga lume. Parodontita nu are doar repercusiuni dramatice asupra statusului oral, ci este considerată şi un factor de risc pentru multe boli sistemice de natură inflamatorie şi pentru complicaţiile acestora cum sunt: diabetul zaharat [33], boala cardiovasculară aterosclerotică şi accidentele acute - accidentul vascular cerebral $[23,29]$ şi infarctul miocardic $[18,34]$, artrita reumatoidă [35], neurodegenerescenţă patologică [36], naşterea prematură [37].

Articolele cuprinse în studiu, inclusiv prezentul articol, susţin că parodontita reprezintă un factor de risc independent pentru accidentul vascular cere- bral, dar nu şi pentru infarctul lacunar $[25,38]$. Ţesuturile parodontale foarte inflamate, inflamaţia gingivală şi parodontita în stadiu incipient cresc riscul pentru accident vascular cerebral [29], în special în rândul pacienţilor tineri [23,39].

Datele din literatură sugerează o asociere între accidentul vascular cerebral, parodontită şi sex. A fost observată o prevalenţă crescută a formelor moderate şi severe de parodontită la pacienţii de sex masculin din grupul pacienţilor cu accident vascular cerebral, faţă de pacienţii de sex feminin [40].

Mecanismul fiziopatologic de conexiune între parodontită şi accidentul vascular cerebral îl constituie cantitatea mare de mediatori inflamatori produşi local parodontal şi care sunt deversaţi în circulaţia generală sau produşi sistemic, ca reacţie la bacteriemia cu bacterii parodontopatogene [20]. Parodontita este caracterizată de pierderea ataşamentului clinic şi resorbţia osoasă, acompaniate de transformarea şanţului gingival în punga parodontală [41]. Ca urmare a acestor transformări, biofilmul subgingival proliferează spre apical. Proliferarea biofilmului şi lipsa ataşamentului deschid poarta de intrare a bacteriilor şi a produşilor lor în circulaţie [42], ceea ce declanşează o fază acută de inflamaţie sistemică, demonstrată de nivelurile crescute serice de proteină C reactivă [43]. Cantităţi crescute de proteină $C$ reactivă sunt secretate şi local parodontal, în locusurile afectate [44]. Proteina $\mathrm{C}$ reactivă este un marker de inflamaţie sistemică considerat predictor al infarctului cerebral ulterior [45].

Prezenţa salivară a unor patogeni parodontali ca Aggregatibacter actinomycetemcomitans [2] şi Porphyromonas gingivalis [15], dar şi inflamaţia sistemică crescută au fost asociate cu accidentul vascular cerebral. Pacienţii cu accident vascular cerebral au avut un număr şi o prevalenţă crescută de locusuri afectate de parodontită faţă de pacienţii fără accident vascular cerebral [15], ceea ce susţine faptul că creşterea afectării parodontale creşte încărcătura inflamatorie sistemică.

Nivelurile crescute de anticorpi IgA faţă de Porphyromonas gingivalis au precedat recidiva accidentului vascular cerebral, la pacienţii cu antecedente de boală cerebro- sau cardiovasculară [45].

Deşi parodontita dezvoltă un răspuns inflamator local, acesta poate predispune la un status proinfla- 
mator sistemic, ceea ce are efecte negative la distanţă, asupra altor sisteme şi organe [30,46-48].

Această interconexiune parodontită - accident vascular cerebral este foarte importantă, având în vedere beneficiile pe care tratamentul parodontal 1-ar putea avea asupra scăderii inflamaţiei sistemice şi, deci, asupra reducerii riscului şi incidenţei accidentului vascular cerebral. S-a raportat că incidenţa accidentului vascular cerebral hemoragic a fost semnificativ mai scăzută la pacienţii cu parodontită care au beneficiat de tratament pentru parodontită, faţă de pacienţii cu parodontită netrataţi parodontal [31].

\section{CONCLUZII}

Datele prezentate în acest prezent articol susţin relaţia de asociere între parodontită şi accidentul vascular cerebral. Parodontita a fost un factor de risc independent pentru boala cerebrovasculară.

Tratamentul parodontitei poate reduce riscul pentru accident vascular cerebral primar sau recurent.

Sănătatea orală şi tratamentul afecţiunilor inflamatorii şi infecţioase orale sunt foarte importante, nu doar pentru menţinerea sănătăţii orale, dar şi pentru menţinerea unui status de sănătate sistemică.

\section{Mulțumiri}

Această lucrare a fost realizată în cadrul Proiectului de Cercetare Doctorală susţinut de Universitatea de Medicină şi Farmacie „Iuliu Haţieganu“, Cluj-Napoca, România, Nr. contract 1529/15 din 18 ianuarie 2019 şi 2462/14 din 17 ianuarie 2020.

Conflict of interest: none declared Financial support: none declared

\section{BIBLIOGRAFIE}

1. Laudenbach JM, Simon Z. Common dental and periodontal diseases: Evaluation and management. Med Clin North Am. 2014;98(6):123960.

2. Palm F, Lahdentausta L, Sorsa T, Tervahartiala T, Gokel P, Buggle F, Safer A, Becher H, Grau AJ, Pussinen P. Biomarkers of periodontitis and inflammation in ischemic stroke: A case-control study. Innate Immun. 2014;20(5):511-8.

3. Campanella V, Obertii L, Gabrione F, González-Valero V, HernándezMartínez V, Silvestre-Rangil J. Periodontitis and cerebrovascular disease: A new novel in medicine. Journal of Biological Regulators and Homeostatic Agents 2019;33(3 Suppl. 1):135-144.

4. Chapple IL, Genco R; working group 2 of the joint EFP/AAP workshop. Diabetes and periodontal diseases: consensus report of the Joint EFP/AAP Workshop on Periodontitis and Systemic Diseases. J Periodontol. 2013;84(4 Suppl):S106-12.

5. Albandar JM, Rams TE. Global epidemiology of periodontal diseases: An overview. Periodontol 2000. 2002;29(1):7-10.

6. Eke PI, Dye BA, Wei L, et al. Update on prevalence of periodontitis in adults in theUnited States: NHANES 2009 to 2012. J Periodontol. 2015;86:611-622.

7. Frencken JE, Sharma P, Stenhouse L, Green D, Laverty D, Dietrich T. Global epidemiology of dental caries and severe periodontitis - a comprehensive review. J Clin Periodontol. 2017;44(Suppl 18):S94-S105

8. Hugoson A, Sjodin B, Norderyd O. Trends over 30 years,1973-2003, in the prevalence and severity of periodontaldisease. J Clin Periodontol. 2008;35:405-414.

9. Holtfreter B, Kocher T, Hoffmann T, Desvarieux M, Micheelis W. Prevalence of periodontal disease and treatment demands based on a German dental survey (DMSIV). J Clin Periodontol. 2010;37:211219.

10. Thom $T$, Haase N, Rosamond $W$ et al. Heart disease and stroke statistics - 2006 update: A report from the American Heart Association Statistics Committee and Stroke Statistics Subcommittee. Circulation. 2006;113:85-151.

11. Vila-Córcoles $\mathrm{A}$, Forcadell $\mathrm{MJ}$, de Diego $\mathrm{C}$ et al. Incidence and mortality of ischaemic stroke among people 60 years or older in the region of Tarragona, Spain [article in Spanish]. Rev EspSaludPublica. 2015;89:597-605.

12. López-Espuela F, Pedrera-Zamorano JD, Jiménez-Caballero PE, et al. Functional status and disability in patients after acute stroke: $\mathrm{A}$ longitudinal study. Am J Crit Care. 2016;25(2):144-51.

13. Díaz Guzmán J. Cardioembolic stroke: Epidemiology. Neurologia. 2012;27(Suppl 1):4-9.

14. Van Asch CJ, Luitse MJ, Rinkel GJ, van der Tweel I, Algra A, Klijn CJ.Incidence, case fatality, and functional outcome of intracerebral haemorrhage over time, according to age, sex, and ethnic origin: A systematic review and meta-analysis. Lancet Neurol. 2010;9(2):16776.

15. Pillai RS, lyer K, Spin-Neto R, Kothari SF, Nielsen JF, Kothari M. Oral Health and Brain Injury: Causal or Casual Relation? Cerebrovasc Dis Extra. 2018;8(1):1-15.

16. Aarabi G, Thomalla G, Heydecke G, Seedorf U. Chronic Oral Infection: An Emerging Risk Factor for Cerebral Small Vessel Disease? Oral Dis. 2019;25(3):710-719.

17. Mustapha IZ, Debrey S, Oladubu M, Ugarte R. Markers of systemic bacterial exposure in periodontal disease and cardiovascular disease risk: A systematic review and meta-analysis. J Periodontol. 2007;78(12):2289-2302.

18. Romagna C, Dufour $L$, Troisgros $O$, Lorgis $L$, Richard $C$, Buffet $P$, Soulat G, Casillas JM, Rioufol G, Touzery C, Zeller M, Laurent Y, Cottin Y. Periodontal disease: A new factor associated with the presence of multiple complex coronary lesions. Journal of Clinical Periodontology 2012;39(1):38-44.

19. You Z, Cushman M, Jenny NS, Howard G. REGARDS. Tooth loss, systemic inflammation, and prevalent stroke among participants in the reasons for geographic and racial difference in stroke (REGARDS) study. Atherosclerosis. 2009;203:615-9.

20. Leira Y, Seoane J, Blanco M, Rodríguez-Yáñez M, Takkouche B, Blanco J, Castillo J. Association between periodontitis and ischemic stroke: A systematic review and meta-analysis. Eur J Epidemiol. 2017;32(1):43-53.

21. Fagundes NCF, Almeida APCPSC, Vilhena KFB, Magno MB, Maia LC, Lima RR. Periodontitis As A Risk Factor For Stroke: A Systematic 
Review And Meta-Analysis. Vasc Health Risk Manag. 2019;15:519532.

22. Ghizoni JS, Taveira LA, Garlet GP, Ghizoni MF, Pereira JR, Dionísio TJ, Brozoski DT, Santos CF, Sant'Ana AC. Increased levels of Porphyromonas gingivalis are associated with ischemic and hemorrhagic cerebrovascular disease in humans: An in vivo study. J Appl Oral Sci. 2012;20(1):104-12.

23. Lee YL, Hu HY, Huang N, Hwang DK, Chou P, Chu D. Dental prophylaxis and periodontal treatment are protective factors to ischemic stroke. Stroke. 2013;44(4):1026-1030.

24. Sen S, Sumner R, Hardin J, Barros S, Moss K, Beck J, Offenbacher $S$. Periodontal disease and recurrent vascular events in stroke/ transient ischemic attack patients. J Stroke Cerebrovasc Dis. 2013;22(8):1420-7.

25. Leira Y, Blanco M, Blanco J, Castillo J. Association between periodontal disease and cerebrovascular disease. A review of the literature. Rev Neurol. 2015;60:29-38.

26. Diouf M, Basse A, Ndiaye M, Cisse D, Lo CM, Faye D. Stroke and periodontal disease in Senegal: Case-control study. Public Health. 2015;129(12):1669-1673.

27. Lafon A, Tala S, Ahossi V, Perrin D, Giroud M, Béjot Y. Association between periodontal disease and non-fatal ischemic stroke: $\mathrm{A}$ case-control study. Acta Odontol Scand. 2014;72:687-93.

28. Del Brutto OH, Mera RM, Zambrano M, Del Brutto VJ. Severe edentulism is a major risk factor influencing stroke incidence in rural Ecuador (The Atahualpa Project). Int J Stroke. 2017;12(2):201-204.

29. Sen S, Giamberardino LD, Moss K, Morelli T, Rosamond WD, Gottesman RF, Beck J, Offenbacher S. Periodontal Disease, Regular Dental Care Use, and Incident Ischemic Stroke. Stroke. 2018;49(2):355-362.

30. Leira Y, Rodríguez-Yáñez M, Arias S et al. Periodontitis is associated with systemic inflammation and vascular endothelial dysfunction in patients with lacunar infarct [published correction appears in $\mathrm{J}$ Periodontol. 2019;90(8):932]. J Periodontol. 2019;90(5):465-474.

31. Huang JL, Chen WK, Lin CL, Lai CY, Kao CH, Chiang HH, Yang TY, Shih HM. Association between intensive periodontal treatment and spontaneous intracerebral hemorrhage-a nationwide, populationbased cohort study. Medicine (Baltimore). 2019;98(10):e14814.

32. Söder B, Meurman JH, Söder PÖ. Gingival Inflammation Associates with Stroke - A Role for Oral Health Personnel in Prevention: A Database Study. PLoS One. 2015;10(9):e0137142.

33. Liccardo D, Cannavo A, Spagnuolo G, Ferrara N, Cittadini A, Rengo C, Rengo G.Periodontal Disease: A Risk Factor for Diabetes and Cardiovascular Disease. Int J Mol Sci. 2019;20(6):1414.

34. Lam YY et al. Periodontal disease and carotidatherosclerosis: A meta-analysis of 17,330 participants. Int J Cardiol. 2016;203:10441051.

35. Kaur S, Bright R, Proudman SM, Bartold PM. Does periodontal treatment influence clinical and biochemical measures for rheumatoidarthritis? A systematic review and meta-analysis. Semin Arthritis Rheum. 2014;44(2):113-122.

36. Ilievski V, Zuchowska PK, Green SJ, Toth PT, Ragozzino ME, Le K et al. Chronic oral application of a periodontal pathogen results in brain inflammation, neurodegeneration and amyloid beta production in wild type mice. PLoS ONE 2018;13(10):e0204941.

37. Micu IC, Roman A, Ticala F, Soanca A, Ciurea A, Objelean A, lancu M, Muresan D, Caracostea GV. Relationship between preterm birth and post-partum periodontal maternal status: A hospital-based Romanian study. Arch Gynecol Obstet. 2020;301(5):1189-1198.

38. Taguchi A, Miki M, Muto A, Kubokawa K, Migita K, Higashi Y, Yoshinari N. Association between oral health and the risk of lacunar infarction in Japanese adults. Gerontology 2013;59(6):499-506.

39. Sim SJ, Kim HD, Moon JY, Zavras Al, Zdanowicz J, Jang SJ, Jin BH, Bae KH, Paik DI, Douglass CW. Periodontitis and the risk for non-fatal stroke in Korean adults. J Periodontol. 2008;79(9):1652-8.

40. Stănescu loana, Bulboacă Adriana Elena, Micu Iulia Cristina, Bolboacă Sorana D, Feştilă Dana Gabriela, Bulboacă Angelo C, Bodizs Gyorgy, Dogaru Gabriela, Boarescu Paul Mihai, PopaWagnerAurel, Roman Alexandra. Gender Differences in the Levels of Periodontal Destruction, Behavioral Risk Factors and Systemic Oxidative Stress in Ischemic Stroke Patients: A Cohort Pilot Study. J Clin Med. 2020;9:1744.

41. Curtis MA. Periodontal microbiology - the lid's off the box again. J Dent Res. 2014;93(9):840-842.

42. Ebersole JL, Taubman MA. The protective nature of host responses in periodontal diseases. Periodontol 2000. 1994;5:112-141.

43. Ridker PM. Clinical application of C-reactive protein for cardiovascular disease detection and prevention. Circulation. 2003;107(3):363-369.

44. Hosomi N, Aoki S, Matsuo K, Deguchi K, Masugata H, Murao K, Ichihara $\mathrm{N}$ et al. Association of serum anti-periodontal pathogen antibody with ischemic stroke. Cerebrovasc Dis. 2012;34(5-6):38592.

45. Pussinen PJ, Alfthan G, Rissanen H, Reunanen A, Asikainen S, Knekt P. Antibodies to periodontal pathogens and stroke risk. Stroke. 2004;35(9):2020-3.

46. Leira Y, Iglesias-Rey R, Gómez-Lado N, Aguiar P, Sobrino T, D'Aiuto F, Castillo J, Blanco J. Periodontitis and vascular inflammatory biomarkers: An experimental in vivo study in rats. Odontology. 2020;108(2):202-212.

47. Pradeep AR, Hadge P, Arjun Raju P, Shetty SR, Shareef K, Guruprasad CN.Periodontitis as a risk factor for cerebrovascular accident: A case-control study in the Indian population. $J$ Periodontal Res. 2010;45(2):223-8.

48. Tonomura S, Ihara M, Kawano T et al. Intracerebral hemorrhage and deep microbleeds associated with cnm-positive Streptococcus mutans; A hospital cohort study. Sci Rep. 2016;6:20074. 